\title{
Peran Community Resilience di Amerika Serikat dan Inggris dalam
}

\section{Upaya Kontra Terorisme}

\author{
Fauzia Gustarina Cempaka Timur ${ }^{1}$, Jamaluddin Syakirin ${ }^{2}$ \\ fgcempaka@gmail.com, jamalsyakirin@gmail.com
}

\begin{abstract}
Abstrak
Radikalisme adalah salah satu akar penyebab utama dari aksi terorisme. Radikalisasi pada kalangan masyarakat umum menjadi ancaman serius bagi stabilitas keamanan nasional. Masyarakat saat ini rentan menjadi sasaran perekrutan kelompok-kelompok radikal, pembentukan jaringan kelompok radikal transnasional, pengarahan tindak kekerasan dan terorisme bahkan melalui radikalisasi diri sendiri. Kurangnya kepedulian dan sistem pengawasan di dalam komunitas masyarakat dianggap juga menjadi katalisator radikalisme. Karena hal itulah, ketahanan komunitas terhadap ancaman terorisme dan radikalisme merupakan aspek penting dalam berhasilnya kontra-radikalisasi di dalam suatu negara. Terlebih jika komunitas yang berada di dalam suatu negara merupakan komunitas yang pluralistik dan memiliki budaya, bahasa, dan agama yang berbeda. Tulisan ini bertujuan untuk menganalisis peran komunitas dan mengemukakan pentingnya ketahanan dalam komunitas dalam usaha memerangi terorisme. Hasil penelitian menunjukkan bahwa sebagai bagian dari kontra-terorisme, pemerintah harus mengadopsi prinsip, "adanya strategi lebih baik ada dibanding tidak ada sama sekali" jika terkait dengan kerjasama bersama komunitas. Selain itu pemerintah harus dapat berinvestasi secara tepat untuk membangun pengetahuan masyarakat terhadap terorisme. Selanjutnya pemerintah juga perlu untuk memfokuskan kembali pada tujuan akhir pemberantasan terorisme pada deradikalisasi dan hal ini harus dilakukan terpisah dari sifat aksi hulu yang dilakukan komunitas. Terakhir, komunitas harus dipayungi organisasi besar yang merupakan perpanjangan dari program pemerintah yang mengajak masyarakat untuk fokus pada upaya memperkuat ketahanan dan kapasitas semua lini masyarakat yang dianggap rapuh.
\end{abstract}

Kata kunci: Amerika Serikat, Inggris, Kontra terorisme, Peran komunitas

\begin{abstract}
Radicalism is one of the main root causes of acts of terrorism. Radicalization among the society poses a serious threat to the stability of national security. Communities today are vulnerable to the recruitment of radical groups, the formation of radical networks of transnational radicals, the directing of acts of violence and terrorism even through self-radicalization. Lack of awareness within the community and absence of monitoring system from government are also considered to be a catalyst for radicalism. Because of this, community resilience to the threat of terrorism and radicalism is an important aspect of successful counter-radicalization within a country. Especially if the community within a country is a pluralistic community and has different cultures, languages and religions. This paper aims to analyze the role of the community and highlight the importance of community resilience in the fight against terrorism. The results show that as part of counter-terrorism, the government should adopt the principle, "the existence of suffice strategy is better than nothing at all" particularly when it is related to community resilience. In addition, the government should be able to invest

\footnotetext{
${ }^{1}$ Korespondensi: Fauzia Gustarina Cempaka Timur. Prodi Peperangan Asimetris, Kampus Universitas Pertahanan, Kompleks IPSC, Sentul, Jawa Barat. 085692651576.

2 Korespondensi: Jamaluddin Syakirin. Program Studi Doktor Ilmu Sosial, Universitas Airlangga, Surabaya. 085692155899.
} 
properly to build public knowledge of terrorism. Furthermore, the government also needs to refocus on ultimate goals of eradicating terrorism and deradicalisation and this should be done separately from the nature of the upstream action of the community. Finally, the community must be protected by a larger organization that is an extension of a government program that calls on communities to focus on strengthening the resilience and capacity of all fragile communities.

Keywords: Community Resilience, Counterterrorism, United Kingdom, United States

\section{Pendahuluan}

Globalisasi merupakan salah satu fenomena yang paling banyak memberikan pengaruh dalam dinamika kehidupan antar bangsa saat ini, terutama pada isu yang berkaitan dengan kajian hubungan internasional. Globalisasi telah banyak menciptakan peluang dan tantangan baru yang harus dihadapi oleh setiap negara (G. Evans dan J. Newnham, 1998: 504). Salah satu dampak yang ditimbulkan globalisasi adalah semakin mudahnya perpindahan benda atau orang dari suatu tempat ke tempat lain. Perpindahan ini dapat menguntungkan suatu negara karena mendorong geliat pada aspek ekonomi yang membawa keuntungan secara signifikan, tetapi di sisi lain perpindahan ini juga memudahkan imigran dari negara berkembang untuk berpindah dan mencari peruntungan di negara lebih maju, seperti Inggris dan Amerika Serikat, contohnya.

Negara yang menjadi tujuan imigran seperti Inggris dan Amerika Serikat, secara langsung maupun tidak langsung berimplikasi pada kehidupan kota-kota di kedua negara tersebut. Kota di berbagai negara, termasuk Inggris dan Amerika Serikat saat ini membutuhkan keterbukaan dan keterhubungan dalam bentuk regionalisme, nasional, maupun dalam skala global untuk bertahan dalam era globalisasi (M. Castells, 1996). Dengan sifat-sifat tersebut, komunitas yang berada di dalam kota tersebut juga secara langsung dapat menjadi entitas yang bersentuhan langsung dengan dampak positif maupun negatif yang dapat muncul dari kegiatan tersebut. Beberapa dampak yang dapat muncul dapat dilihat dari dua aspek yaitu dampak yang timbul dari alam seperti bencana gempa dan banjir maupun bencana buatan manusia seperti serangan teroris (D. Godschalk, 2003: 136).

Serangan teroris yang terjadi pada 7 Juli 2005 menjadi sebuah serangan yang sangat mengejutkan bagi Inggris, terutama kota London. Terutama karena serangan tersebut dibawa oleh empat orang pengebom yang dianggap datang dari 
komunitas baik di London (R. Briggs, 2010: 971). Hal tersebut menjadi semakin mengejutkan karena saat itu fokus kegiatan kontra-terorisme Inggris sedang condong pada pendekatan outward-looking sehingga kejadian pengeboman tersebut menunjukkan bahwa celah pertahanan terhadap teroris justru terjadi di lingkungan domestik negara Inggris sendiri. Dari kejadian tersebut, kesadaran untuk menggunakan pendekatan yang berbeda dalam upaya kontra-terorisme yang sebelumnya bersifat 'memandang ke luar' menjadi lebih bersifat inward-looking dengan menitikberatkan pada peran komunitas-komunitas di Inggris.

Sedangkan bagi Amerika Serikat, terorisme telah diidentifikasi sebagai masalah bagi keamanannya sejak lama. Namun, peristiwa terorisme pada gedung kembar World Trade Centre di New York menjadikan terorisme sebagai musuh besar di Amerika Serikat. Kejadian tersebut dianggap sebagai penghinaan pada sistem pertahanan dan keamanan sipil maupun militer di Amerika Serikat. Peristiwa ini pula yang membuat Amerika Serikat melakukan berbagai perubahan yang bersifat holistik pada berdampak baik pada institusi pemerintah Amerika Serikat maupun kehidupan masyarakatnya.

Topik tersebutlah yang akan diangkat dalam tulisan ini. Tulisan ini penting terutama pada kajian hubungan internasional, utamanya yang terkait dengan fokus keamanan global untuk menganalisis bagaimana peran komunitas penting bagi pertahanan negara terhadap terorisme yang terjadi di dalam negeri. Negara Inggris dan Amerika Serikat dipilih pada tulisan ini karena negara tersebut memiliki keberagaman yang hampir serupa dengan Indonesia. Dengan banyaknya pendatang yang datang dari berbagai negara berbeda dengan latar belakang agama dan budaya yang berbeda, potensi kerawanan terhadap terorisme semakin besar sehingga usaha kontra-terorisme yang menggunakan basis pendekatan komunitas menjadi lebih penting dalam upaya negara terhadap terorisme. Indonesia sebagai negara yang masih terus belajar menyempurnakan usaha kontra-terorisme dianggap Penulis dapat belajar dari pengalaman Inggris dan Amerika Serikat sehingga ketahanan terhadap terorisme di Indonesia dapat lebih baik. Penulis akan mengkorelasikan usaha kontra-terorisme dan pendekatan melalui basis komunitas yang dimiliki Inggris dan Amerika Serikat dan membandingkan pendekatan yang berbeda melalui elaborasi akhir dari tulisan ini. 


\section{Metode}

Untuk menganalisis pembahasan dalam penelitian ini, penulis melakukan pengumpulan data melalui studi dokumentasi, dalam hal ini adalah data sekunder. Penulis menggunakan data yang diperoleh dari berbagai sumber yang ada seperti buku, jurnal, dan artikel online, yang selanjutnya dilakukan proses analisis dan interpretasi terhadap data-data tersebut sesuai dengan tujuan penelitian. Dalam tahap proses analisis, penulis melakukan analisis data secara kualitatif, yaitu setelah fakta dan data yang mendukung penelitian ini ditemukan melalui sumber-sumber yang kredibel, maka selanjutnya penulis akan menghubungkannya dengan konsep yang relevan, untuk kemudian diambil kesimpulan berdasarkan relevansi dari konsep tersebut. Mengingat bahwa penelitian ini bersifat perbandingan antara dua obyek penelitian, yaitu praktek kontra-terorisme di Amerika dan Inggris, maka cakupan pembahasannya hanya pada data faktual pengalaman dari dua negara tersebut.

\section{Hasil dan Pembahasan}

\section{Keterlibatan Komunitas dalam Kegiatan Kontra-Terorisme Community Resilience di Inggris}

Kejadian terorisme di Juli 2005 telah menjadi sebuah bukti bahwa terdapat jaringan kelompok radikal yang rumit dalam komunitas muslim di beberapa bagian kota negara Inggris sehingga penting bagi pemerintah Inggris untuk melakukan strategi berbasis komunitas. Kejadian terorisme yang dikenal sebagai kejadian 7/7 pun mendorong adanya ide pendekatan yang lebih menyentuh pada basis komunitas. Ide pendekatan dengan basis komunitas untuk usaha kontra-terorisme ini sebenarnya bukan hal yang baru dalam pendekatan dengan basis komunitas. Sebelumnya metode yang sama digunakan untuk meredam kegiatan terorisme yang sebelumnya berlarutlarut di Irlandia Utara.

Sebelum kejadian tersebut terjadi, secara konstan Pemerintah Inggris menggunakan pendekatan melihat ke luar dengan asumsi untuk mempertahankan negara tersebut terhadap serangan terorisme yang datang dari luar. Meski begitu, kejadian tersebut membuktikan bahwa peristiwa terorisme yang terjadi di London justru berasal dari masyarakatnya sendiri. Sejak saat itu pula dirancang Undang-Undang mengenai pelibatan komunitas dalam strategi kontra-terorisme di Inggris sebagai upaya 
yang lebih inward-looking. Strategi kontra-terorisme yang dilakukan oleh pemerintah Inggris ini menggunakan tiga slogan yaitu 'Pursue', Protect', dan 'Prepare'. Pendanaan untuk menjalankan strategi tersebut terus ditingkatkan oleh pemerintah Inggris, yang sebelumnya pada awal pengimplementasian kebijakan berada pada 6 Juta Poundsterlings hingga pada tahun 2008 mencapai 140 Juta Poundsterlings (HM Government, 2009: 16). Adanya peningkatan dalam hal pendanaan menunjukkan sikap pemerintah Inggris yang menilai keterlibatan komunitas sangat penting bagi berhasilnya strategi kontra-terorisme di negara tersebut.

Beberapa alasan pemerintah Inggris mengimplementasikan hal tersebut secara cepat dalam upaya kontra-terorisme salah satu alasannya adalah karena peristiwa teror $7 / 7$ membuktikan bahwa ancaman teroris yang paling berbahaya dapat muncul dari kelompok kecil yang minoritas di dalam masyarakat yang merasa termarjinalisasi oleh pemerintah. Kondisi sebagai minoritas dan pihak yang dimarjinalisasi membuat komunitas tersebut rentan mengalami radikalisasi. Terlebih bagi kelompok dan individu yang merasa termarjinalisasi, jika pihak tersebut gagal menemukan identitas lain yang dapat dianggap sebagai identitas dirinya maka radikalisasi akan semakin mudah mempengaruhi jalan pikiran individu tersebut untuk ikut dalam gerakan terorisme. Minimalnya pengawasan dari pemerintah London sebelumnya, dianggap sebagai salah satu celah yang dimanfaatkan teroris untuk melakukan aksinya. Hal tersebut pula yang menjadi sebuah 'pukulan' besar bagi pemerintah Inggris sehingga mengubah sudut pandangnya terhadap peran community resilience dalam melakukan upaya kontra-terorisme. Dengan adanya undang-undang yang berkaitan dengan community resilience menandakan pemerintah Inggris memandang keterlibatan masyarakat berperan sentral dalam strategi kontra-terorisme.

Tujuan utama dari undang-undang yang melibatkan peran sentral masyarakat dalam untuk mengintersepsi rencana serangan teroris yang mungkin terjadi di Inggris. Selain itu undang-undang tersebut dilakukan untuk mengacaukan sel teroris yang bersarang di komunitas-komunitas di Inggris. Pemerintah Inggris mengakui bahwa komunitas-komunitas perlu diajak untuk bersama untuk mewujudkan keberhasilan strategi ini, terutama pada komunitas muslim di Inggris. Peran utamanya adalah untuk menghindarkan kalangan muda komunitas muslim dari kelompok radikal yang paling dekat dengannya. Sehingga penting bagi komunitas untuk membuat tiap 
komunitas cukup 'tahan' atau resilient untuk merespon hal tersebut serta menentang segala jenis ekstrimisme dari dalam.

Menurut Briggs, terdapat empat cara utama sekaligus alasan yang dapat membuat sebuah komunitas dapat berperan efektif dalam strategi kontra-terorisme (R. Briggs, 2010: 972-974). Pertama dan yang paling efektif adalah jika masyarakat dapat terintegrasi dengan baik melalui komunitas yang komunikatif dengan polisi setempat. Dengan adanya komunitas yang komunikatif, maka akan mempermudah terbentuknya sistem peringatan dini bagi aparat baik militer, polisi maupun agen intelijen yang membutuhkan informasi tentang individu atau kelompok tertentu yang dianggap radikal dan membahayakan bagi situasi kondusif.

Metropolitan Police Service sebagai aparat yang bertugas di wilayah London misalnya, menetapkan slogan 'If you suspect it, report it' (lihat Gambar 1.). Tidak hanya menerima laporan secara langsung melalui botline telepon dari masyarakat London tetapi juga memberikan komunitas di ruang siber yang khusus digunakan sebagai tempat masyarakat dan komunitas untuk melaporkan berbagai materi di dunia siber yang dianggap berkaitan dengan dugaan kegiatan teroris. Dari poin pertama ini ditujukan agar strategi 'prevent' dan 'pursue' dapat disatukan.

Gambar 1. Kampanye If you suspect it, report it'

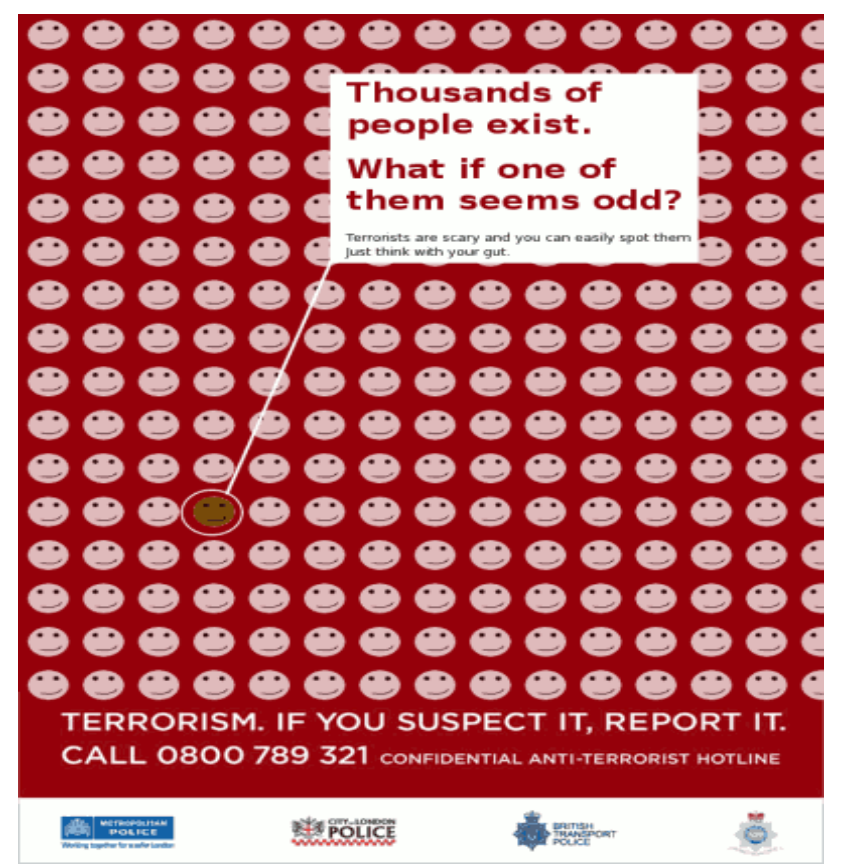


Kedua, komunitas dapat membantu pencegahan terorisme dari akar hulunya. Hal tersebut dilakukan dengan cara melindungi kelompok muda terkena pengaruh komunitas yang dianggap membawa radikalisasi yang dapat berujung pada aksi kekerasan atau bahkan terorisme. Aspek ini didukung oleh banyaknya pandangan yang melihat bahwa kelompok muda merupakan komunitas yang paling rawan terpengaruh radikalisasi (Departemen Anak, Sekolah dan Keluarga Inggris, 2008). Hal tersebut didorong oleh mudahnya pihak yang berideologi radikal untuk menyatu dan membaur dengan kelompok muda. Selain itu juga penyebaran diskursus ekstrimisme global dan ketersediaan bahan-bahan bacaan yang mendorong terhadap ekstrimisme lebih mudah ditemukan pada kelompok dengan individu berumur muda dibandingkan dengan yang berumur lebih tua. Di samping itu, identitas untuk berada dalam kelompok dan komunitas tertentu masih samar sehingga lebih mudah untuk disusupi ideologi baru. Besarnya tingkat pengangguran dan masih adanya pengecualian dari sistem masyarakat sosial terhadap kelompok muda, mudahnya tersulut dan terprovokasi dendam terhadap pihak tertentu, serta kurangnya kepercayaan individu muda terhadap struktur politik dan sistem sosial masyarakat juga membuat kelompok muda rentan sebagai akar hulu dari gerakan terorisme (HM Government, 2008). Memperhatikan generasi muda yang ada di wilayah merupakan upaya komunitas dan masyarakat untuk ikut bersama aparat yang berwenang meningkatkan community resilience dalam menghadapi terorisme.

Ketiga, komunitas dapat digunakan sebagai penyangga dari dendam dan amarah yang dimiliki teroris dan dapat berperan untuk memastikan agar dendam dan amarah yang diwujudkan dalam ideologi radikalisme tersebut agar tidak tersebar semakin luas dalam masyarakat. Dengan adanya pihak-pihak yang mendukung ideologi radikalisme, membiarkan tumbuhkembangnya ideologi tersebut atau bahkan menjadi pelaku secara sembunyi-sembunyi atau bahkan terang-terangan harus tetap diwaspadai komunitas di dalam masyarakat sebagai aksi yang dapat menyuburkan terorisme. Terbukti secara teoritis bahwa terorisme membutuhkan banyak orang untuk mempercayai tujuan besar atau ideologi yang diikuti oleh teroris tersebut. Mempengaruhi orang lain mengenai ideologi radikalisme yang dimilikinya menjadi agenda penting bagi teroris, baik jika komunitas dari tempatnya berasal meyakini secara penuh ideologi tersebut atau bahkan jika meragukannya. Dalam kasus Inggris, jika 
pemerintah Inggris ingin bekerjasama dan mendapat kepercayaan dari komunitas yang dianggap dapat menyebarkan ideologi radikal, komunitas muslim atau komunitas pendatang asing misalnya, maka pemerintah harus bekerja keras untuk memberikan empati yang lebih besar bagi banyak ketidakadilan yang dihadapi komunitas muslim dan komunitas pendatang di Inggris sehingga kepercayaan yang akan diberikan oleh komunitas-komunitas tersebut pun berdampak positif pada tingkat community resilience di Inggris.

Keempat, sistem di Inggris yang memberlakukan peraturan bagi aparat kepolisian terutama Metropolitan Police Service untuk mendapatkan persetujuan dari area yang berada di bawah pengawasannya untuk melakukan berbagai kegiatan penegakan hukum di wilayah tersebut juga dapat meningkatkan kepercayaan masyarakat terhadap aparat yang berwenang. Hal tersebut juga menunjukkan bahwa masyarakat dan komunitas yang terdapat di dalamnya merupakan bagian penting dari keputusan untuk penegakan hukum baik yang berkenaan dengan keselamatan komunitas tersebut secara langsung maupun tidak, terlebih yang berkaitan dengan terorisme.

\section{Community Resilience di Amerika Serikat}

Peristiwa peledakan gedung World Trade Centre (WTC) dengan cara menabrakan pesawat yang dibajak oleh kelompok teroris dari Al-Qaida yang dilakukan oleh 19 orang berkewarganegaraan asing sebenarnya bukanlah kejadian terorisme yang pertama terjadi di Amerika Serikat (AS). Jauh sebelum peristiwa 9/11, AS pernah mendapat serangan pemboman yang terkait dengan aksi terorisme. Sejarah mencatat, pemboman tersebut terjadi pada tahun 1910 di gedung Los Angeles Time yaitu sebuah kantor berita di salah satu negara bagian di AS (Spartacus, 2016). Berbagai macam kegiatan yang tergolong sebagai aksi terorisme juga pernah dihadapi oleh AS dari teroris berideologi sayap kanan, sayap kiri hingga yang memiliki motif nasionalisme. Teroris sayap kanan adalah seperti Ku Klux Klan, sayap kiri seperti golongan eks militansi, dan kelompok dengan motif nasionalisme seperti Nasionalis Puerto Rico.

Kejadian-kejadian tersebut menunjukkan bahwa terorisme bukan lagi dilihat sebagai hal yang baru lagi di AS. Meski begitu, kejadian yang menimpa WTC harus diakui telah mengubah cara pandang AS terhadap terorisme. Terlebih setelah Presiden AS saat itu, George W. Bush, mengeluarkan pernyataan tentang Global War 
on Terrorism (GWOT) yang dengan keras memperingatkan negara-negara di dunia sebuah ultimatum "either you with us or with the terrorists". Kejadian yang banyak disebut sebagai peristiwa 9/11 juga menjadi justifikasi bagi AS untuk kemudian membentuk sebuah institusi baru yaitu Departement of Homeland Security (DHS). Keberadaan DHS merupakan respon nyata AS terhadap masalah keamanan yang muncul di dalam negeri, khususnya yang terkait terorisme.

DHS AS memiliki beberapa program prioritas untuk melibatkan peran komunitas publik dalam usaha kontra terorisme. Program prioritas yang diarahkan kepada kesadaran publik menjadi salah satu upaya yang dipilih karena pemerintah AS menyadari bahwa kerugian yang dialami oleh AS karena serangan terorisme bukanlah direct damage seperti, hilangnya nyawa, cedera, dan kerusakan properti (Gerd Gigerenzer, 2006: 347) tetapi lebih besar daripada itu yakni dampak psikologi dari serangan terorisme (Siobhan Gorman, 2013). Melalui pertimbangan tersebutlah pendekatan yang diambil oleh AS di bawah koordinasi DHS berbeda dengan yang diimplementasikan pada negara Inggris.

Gambar 2. Situs Publik DHS yang menampilkan agenda olahraga tahunan Super Bowl sebagai perhatian utama

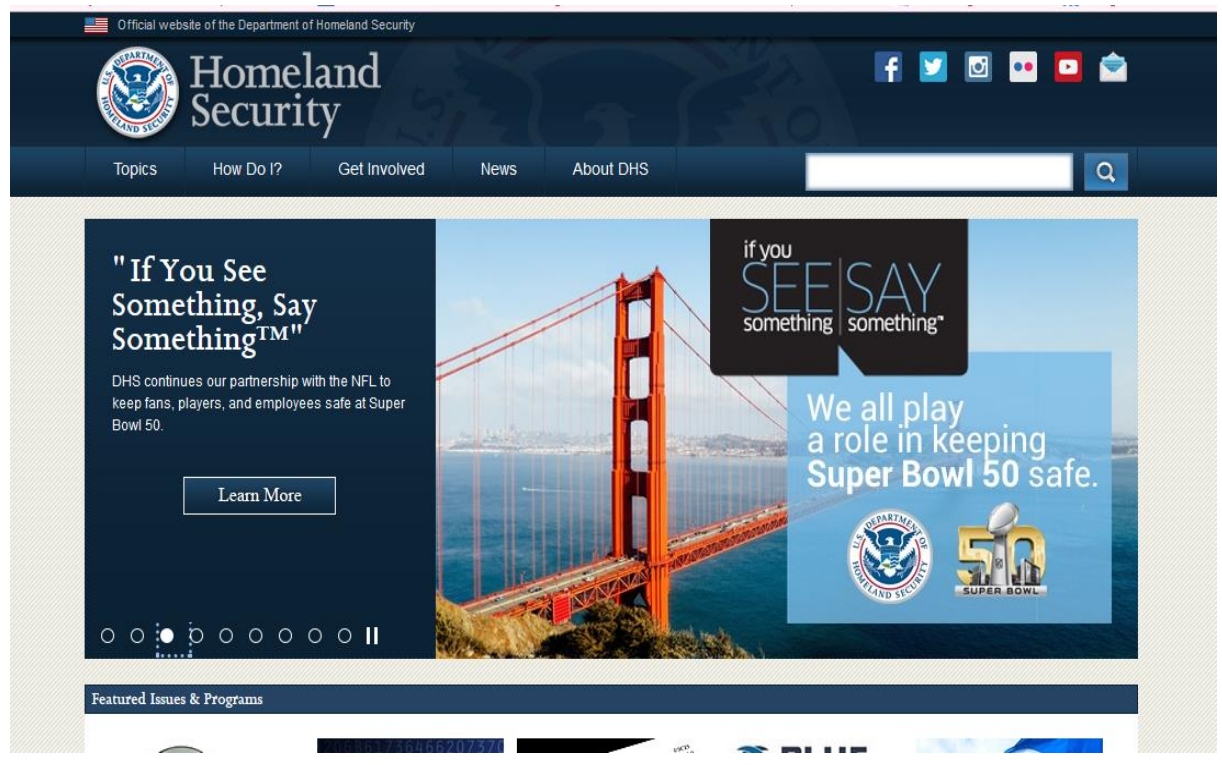

Program yang dilakukan oleh DHS sebagai upaya meningkatkan community resilience yakni; (1) Edukasi dan peningkatan kepedulian publik terhadap terorisme; (2) 
Partisipasi publik untuk melakukan pelaporan atas aktivitas mencurigakan; (3) Partisipasi publik dalam kesiapsiagaan mengadapi situasi gawat dan mendesak; (4) Peningkatan komunikasi pemerintah dengan publik yang lebih intens dalam masalah terkait terorisme.

Pertama, program edukasi dan kesadaran publik dilaksanakan oleh struktur pemerintahan federal di AS yang dipimpin oleh DHS (DHS 2016). DHS memiliki tanggung jawab untuk memastikan keselamatan publik di dalam negeri AS. Mendukung tujuan tersebut DHS juga memiliki beberapa program seperti DHS Public Website dan Ready Campaign. Sejak Februari 2003, "Ready: Prepare. Plan. Stay Informed" merupakan bagian dari Ready Campaign. Untuk program ini DHS membagi tiga bagian yaitu 1) Ready America merupakan website untuk mengedukasi publik untuk siap dan sigap dalam merespom keadaan gawat, baik karena bencana alam ataupun potensi serangan teroris; 1) Ready Business untuk pemilik bisnis kecil dan menengah, dan 3) Ready Kids yang bertujuan untuk meningkatkan kepedulian anak terhadap masalah tersebut dan mempersiapkan kewaspadaan orang tua.

Gambar 3. Kampanye Ready: Prepare. Plan. Stay Informed

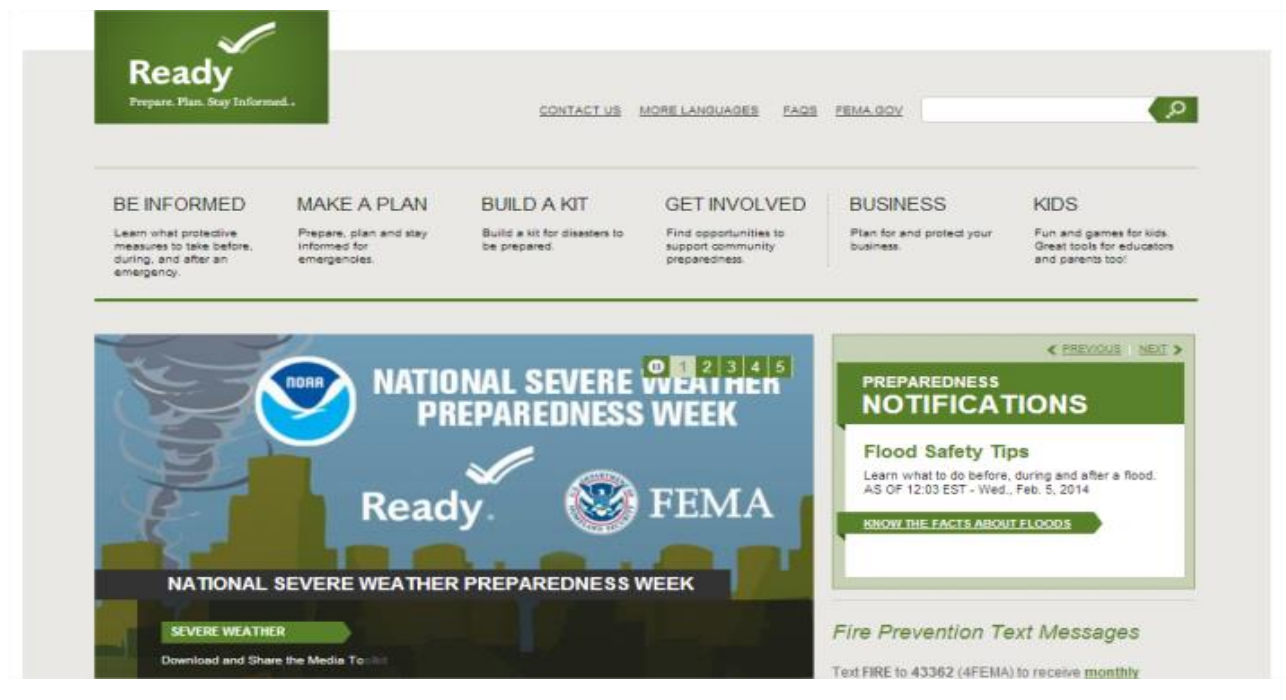

Selain program yang dimiliki DHS, AS juga memiliki Federal Emergency Management Agency (FEMA) yang bertujuan mengedukasi publik untuk mengurangi dampak dari bencana nasional dimulai dari bencana alam, aksi terorisme dan bencana 
buatan manusia lainnya (Fema.gov 2016). Selain itu terdapat beberapa program yang diluncurkan DHS untuk melakukan edukasi dan kesadaran publik terhadap terorisme.

Kedua, program partisipasi publik terhadap pelaporan aktivitas mencurigakan. Salah satu yang dimiliki AS adalah Nationwide Suspicious Activities Reporting Initiative (NSI) yang merupakan upaya untuk memenuhi standar Suspicious Activity Reporting (SAR). NSI merupakan program yang diluncurkan oleh Program Manager for the Information Sharing Environment (PM-ISE) dibawah koordinasi Office of Domestic National Intelligence (ODNI). Program ini memiliki tujuan untuk mengembangkan, mengevaluasi, dan menerapkan proses dan kebijakan umum untuk mengumpulkan, mendokumentasikan, pengolahan, analisis, dan berbagi informasi tentang kegiatan yang mencurigakan dan terkait terorisme. Dalam kampanye untuk meningkatkan partisipasi masyarakat dan komunitas di dalammya agar lebih proaktif dalam melaporkan kejadian mencurigakan yang terjadi di AS dibentuklah kampanye 'If You See Something, Say Something. Kampanye tersebut mendukung inisiatif yang akan memastikan bahwa peserta NSI di semua tingkat pemerintahan mengadopsi kebijakan yang konsisten dan prosedur yang mendorong pembagian yang lebih luas dari SAR yang berkaitan dengan terorisme (Ise.gov 2016).

Gambar 4. Berbagai Print Materials dari Kampanye 'If You See Something, Say Something'
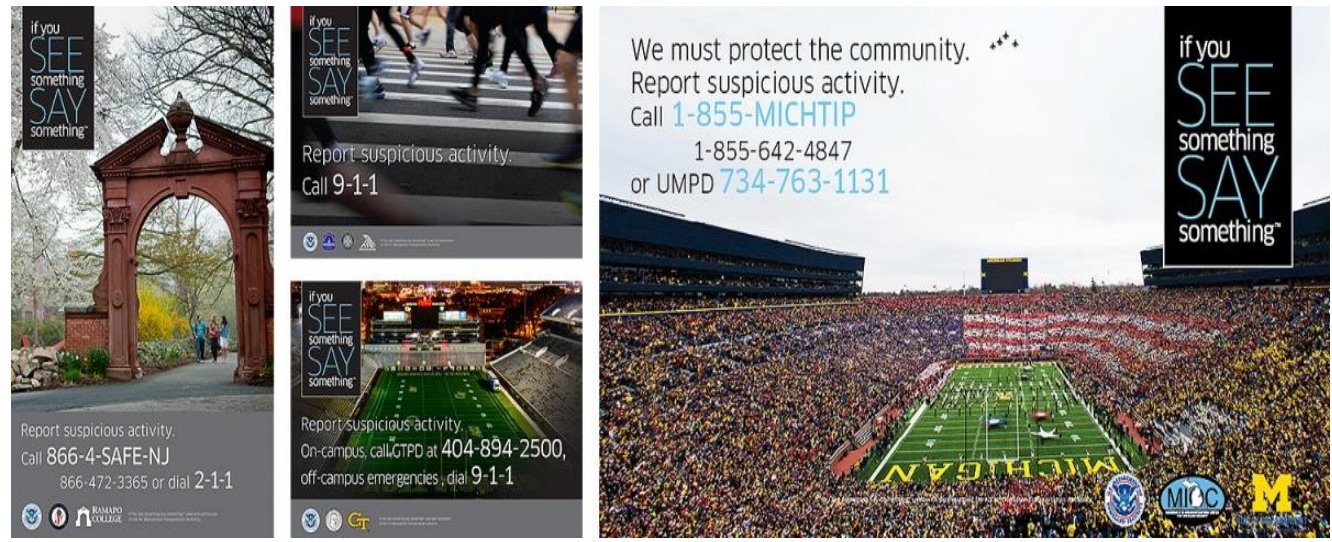

Ketiga, partisipasi publik dalam kesiapan mengadapi situasi gawat. Salah satu program yang dimiliki AS di bawah DHS adalah Citizen Corp. Misi dari Citizen Corp yaitu memanfaatkan kekuatan dari setiap individu melalui pendidikan, pelatihan, dan 
layanan relawan untuk menciptakan masyarakat yang lebih aman, lebih kuat, dan lebih siap untuk menanggapi ancaman terorisme, kejahatan, masalah kesehatan masyarakat, dan segala jenis bencana (Citizencorps.gov 2016).

Keempat, komunikasi pemerintah dengan publik dalam hal-hal yang terkait terorisme. Selain melalui media cetak, elektronik, dan laman di ruang siber, Pemerintah AS juga membuka jalur bagi masyarakat untuk berbagi opini yang terkait dengan isu terorisme melalui Emergency Broadcast System (EAS). Di bawah regulasi pemerintah federal, semua komunikasi kabel, radio, dan satelit harus menyediakan waktu untuk siaran dari presiden saat terjadi keadaan darurat. EAS merupakan upaya pemerintah berkomunikasi saat keadaan sedang darurat dengan mengontrol secara penuh semua saluran komunikasi publik (Fcc.gov 2016). Melalui implementasi program-program tersebutlah Pemerintah AS menunjukkan kepeduliannya untuk melibatkan masyarakat dan komunitas yang ada di dalamnya untuk meningkatkan community resilience negara tersebut sebagai upaya kontra-terorisme di AS.

\section{Tantangan dan Peluang: Pembentukan Community Resilience dalam Usaha Kontra-Terorisme}

Resilience atau ketahanan adalah sebuah proses yang berhubungan dengan serangkaian kapasitas untuk beradaptasi dan menanggapi secara positif setelah terjadinya sebuah gangguan yang menimbulkan ketegangan (F. H. Norris, S. P. Stevens, B. Pfefferbaum, et. al., 2007: 131). Jika penjelasan mengenai ketahanan tersebut digandeng dengan kata komunitas atau community maka akan berarti sebuah proses yang berhubungan dengan serangkaian kemampuan beradaptasi yang memiliki sifat salingberkaitan dalam sebuah konstituen populasi setelah melewati sebuah gangguan yang menimbulkan ketegangan (F. H. Norris, S. P. Stevens, B. Pfefferbaum, et. al., 2007: 131). Usaha yang besar untuk melibatkan komunitas dalam strategi kontraterorisme telah dilakukan oleh pemerintah Inggris dan Amerika Serikat. Inggris menggunakan community resilience sebagai program yang diandalkan dalam melawan terorisme. Berbeda halnya dengan Amerika Serikat yang menggunakan upaya community resilience sebagai program pendukung dari program yang bersifat ofensif sebagai andalan untuk melawan terorisme. Meski menggunakan pendekatan yang berbeda pada masing-masing negara, namun tetap terdapat kesamaan dalam kedua negara tersebut 
yaitu intensifnya pelibatan masyarakat dan komunitas di dalamnya pada usaha memberantas terorisme.

Meski usaha tersebut telah dilakukan oleh kedua negara tersebut secara intensif, tetapi terdapat beberapa tantangan yang harus dihadapi kedua negara tersebut agar dapat menciptakan community resilience yang optimal dan sesuai dengan yang diharapkan kedua negara tersebut; Pertama, jika setiap komunitas dalam masyarakat sadar akan potensi yang dimiliki dari peran yang dapat dilakukan dalam masyarakat, maka komunitas tersebut harus melakukannya sesuai dengan yang dipercayakan serta melakukannya dengan sungguh-sungguh sebagai bentuk penghargaan pada aparat polisi atau aparat lokal yang bertugas. Selain itu, institusi yang menjadi aparat penegak hukum harus dapat dipercaya dalam hal memperlakukan informasi tersebut sebagaimana mestinya. Dengan begitu diharapkan masyarakat dan komunitas yang berada di dalamnya dapat memberikan informasi yang dibutuhkan institusi tersebut. Jika masyarakat dalam komunitas merasa dirinya dialienasi atau dimarjinalisasikan atas pandangannya dan pendapatnya, maka strategi melibatkan komunitas masyarakat tidak akan berhasil secara optimal.

Kedua, untuk kerjasama ini dapat berhasil secara efektif, komunitas dan aparat harus melibatkan kesalingpahaman atas isu terorisme dan bagaimana langkahlangkah yang tepat menanggapi indikasi maupun kejadian tersebut. Perbedaan interpretasi atas kebijakan secara internal dari aparat pemerintah sendiri, baik antar departemen maupun antar aparat polisi, militer dan lainnya harus sangat diminimalkan agar tidak menimbulkan kerugian pada upaya kontra-terorisme.

Ketiga, masih adanya kekhawatiran dari masyarakat akan kemampuan otoritas setempat untuk mencapai agenda 'prevent'. Hal ini bisa diminimalisasikan dengan meningkatkan pemahaman otoritas penegak hukum mengenai komunitas lokal muslim maupun komunitas pendatang lainnya yang dapat menimbulkan ketidakpercayaan dari komunitas-komunitas tersebut. Sehingga tidak heran jika banyak otoritas lokal di Inggris, misalnya, yang melakukan community mapping dan pemetaan kebutuhan komunitas dibanding menggunakan kesempatan tersebut untuk membangun hubungan dengan komunitas lokal.

Keempat, masih banyaknya pandangan negatif media terhadap muslim dan menimbulkan Islamophobia di kalangan komunitas selain muslim di negara Inggris 
maupun Amerika Serikat yang akhirnya secara alami mempengaruhi cara komunitas muslim melakukan hubungan dengan komunitas lain. Komunitas Islam di Inggris dan Amerika Serikat dipandang sebagai ancaman terhadap budaya tradisional negara setempat bahkan pada titik yang paling ekstrim dianggap tidak memiliki kesamaan apapun antara barat dan Islam. Hal ini mengkhawatirkan bagi pemerintah di kedua negara karena dengan lemahnya kepercayaan komunitas terhadap pemerintah dapat mengakibatkan dampak yang lebih buruk bagi kemauan komunitas Muslim untuk menerima, mendukung dan bergabung dengan strategi kontra-terorisme yang diusung oleh pemerintah.

\section{Kesimpulan}

Meskipun banyak negara terus berjuang dengan prinsip-prinsip untuk melakukan kemitraan praktis dengan aktor-aktor non-negara pada agenda keamanan dan strategi kontra-terorisme, namun pendapat yang berbeda dari tiap-tiap kementerian di Inggris terutama jika mengkaitkannya dengan pentingnya melibatkan peran serta komunitas di dalam strategi tersebut. Otoritas penegak hukum lokal yang secara utuh tidak memahami mengenai hubungan dengan komunitas Muslim dan komunitas pendatang dapat mengakibatkan dampak buruk yang tidak dapat dihindari. Sehingga penting untuk kedua negara mewujudkan kesepahaman dari berbagai sisi atas kebijakan ini. Dalam situasi media dan lingkungan politik yang serba sulit dan sensitif, kebijakan ini tetap menjadi prioritas bagi strategi kontra-terorisme yang dimiliki Inggris.

Namun, kejadian 9/11 di Amerika Serikat membuat pendekatan dengan basis komunitas ini sedikit lebih tumpul melihat bahwa tren yang muncul bersifat internasional, di luar negeri dan ancaman transnasional yang terkoordinasi (R. Briggs, C. Fieschi dan L. Lownsbrough, 2006: 19). Beberapa resep yang dapat diterapkan di negara-negara tersebut jika mengkaitkannya dengan peran serta komunitas dalam strategi kontra-terorisme adalah pemerintah harus mengadopsi strategi lebih baik ada dibanding tidak ada sama sekali jika berhubungan dengan kerjasama bersama komunitas. Selain itu pemerintah harus dapat berinvestasi secara tepat untuk membangun pengetahuan masyarakat terhadap terorisme dibanding membayar konsultan dari luar yang tidak mengerti mengenai daerah tersebut. Selanjutnya 
pemerintah juga perlu untuk memfokuskan kembali pada tujuan akhir pemberantasan terorisme pada deradikalisasi dan hal ini harus dilakukan terpisah dari sifat aksi hulu yang dilakukan komunitas. Terakhir, komunitas harus dipayungi organisasi besar yang merupakan perpanjangan dari program pemerintah yang mengajak masyarakat untuk fokus pada upaya memperkuat ketahanan dan kapasitas semua lini masyarakat yang dianggap rapuh, tidak hanya Muslim bagi Inggris, atau kelompok tertentu di Amerika Serikat.

\section{Referensi}

\section{Pustaka Buku}

Briggs, R., Fieschi C., dan Lownsbrough L. 2006. Bringing it home: community-based approaches to counterterrorism, London. Demos.

Castells, M. 1996. the Information Age: Economy, Society and Culture Vol. 1: The Rise of the Network Society. Oxford. Blackwell.

Evans G., dan Newnham J. 1998. Dictionary of International Relations. London. Penguin Books.

HM Government. 2008. The Prevent Strategy: a guide for local partners in England. London. TSO.

HM Government. 2009. Pursue, Prevent, Protect, Prepare: the United Kingdom's strategy for countering international terrorism. London. TSO.

\section{Pustaka Jurnal}

Briggs, R. 2010. 'Community Engangement for Counterterrorism: Lessons from the United Kingdom', International Affairs, Vol.86, no.4, Oxford. Blackwell.

Gigerenzer, G. 2006. "Out of the Frying Pan into the Fire: Behavioral Reactions to Terrorist Attacks," Risk. Analysis, vol. 26, no. 2.

Godschalk, D. 2003. 'Urban hazard mitigation: creating resilient cities', Natural Hazards Review, Vol. 4, No.3.

Norris, F.H., Stevens S. P., Pfefferbaum B., et. al. 2007. 'Community Resilience as a Metaphor, Theory, Set of Capacities and Strategy for Disaster Readiness', Journal of Community Psychology, Oklahoma. Springer Science+Business Media. 


\section{Pustaka Online}

Citizen Corps. (2016) “Citizen Corps Council”. Diakses 16 Februari 2016 pada http://www.citizencorps.gov/cc/index.do

Departemen Anak, Sekolah dan Keluarga Inggris (2008). "Radicalisation processes leading to acts of terrorism: a concise report prepared for the European Commission's expert group on violent radicalization”, rilis 15 Mei 2008. Diakses $13 \quad$ Februari $2016 \quad$ pada http://www.clingendael.nl/publications/2008/20080500_cscp_report_v ries.pdf

DHS. (2016). "Department Subcomponents and Agencies”. Diakses 16 Februari 2016 pada http://www.dhs.gov/xabout/structure/

Federal Communications Commission. (2016). Emergency Alert System. Diakses 16 Februari 2016 pada http://www.fcc.gov/pshs/services/eas/

FEMA. (2016). "About FEMA”. Diakses 16 Februari 2016 pada http://www.fema.gov/about/index.shtm

Gorman, S. (2016). "Fear Factor: Beyond a Panic Driven Approach to Homeland Security" in National Journal, 16 Mei 2013. Diakses 16 Februari 2016 pada http://www.govexec.com/dailyfed/0503/051603nj1.htm

Ise.gov. (2016). "Nationwide Suspicious Activities Reporting (SAR) Initiative". Diakses 16 Februari 2016 pada http://www.ise.gov/pages/sar-initiative.html Spartacus. (2016) “Bombing of the Los Angeles Times”. Diakses pada 15 Februari 2016 pada http://www.spartacus.schoolnet.co.uk/USACbombing.htm 